\section{PRISON MANAGEMENT.}

THE whole tendency of the Prison Act of 1877, which came into operation on April 1st last, has been undoubtedly towards greater economy of administration and increased severity toward the prisoner. At the same time the powers of the Visiting Justices, whose duty it was to control undue severity and see that strict justice only was meted to the inmates, have, if the evidence given by Sir William $\mathrm{H}$. Wyatt, Chairman of the Visiting Justices Committee, at the recent inquest at the Clerkenwell House of Correction, is correctly reported, been greatly curtailed, and consequently the Committee is no longer "the slightest protection to the prisoner." Whilst the extraordinary, we might almost say sensational, evidence adduced at the inquest just alluded to, is still fresh in our minds, the first report of the Commissioners of Prisons under the new Act comes opportunely to enable us to form an opinion for ourselves as to the merits and demerits of the present system.

And first as regards the plank system, about which so much has been recently said. The use of the plank instead of mattress is certainly no innovation, the Act of 1865 having authorised its use for convicted prisoners "during such time as may be determined by the rules of the prison," but the credit of formulating the method of applying the punishment belongs to the present Act, and the ingenuity displayed in making it as formidable as possible is worthy the professed torturers of the Middle Ages. Thus, for example, "a prisoner in the first stage will be employed ten hours daily in strict separation on first-class hard labour, of which six to eight hours will be on crank, treadwheel, or work of a similar nature, and sleep on a plank bed without a mattress. A prisoner in the second stage will be employed as in the first stage until he has completed one month of imprisonment, and afterwards on hard labour of the second class, and sleep on a plank bed without a mattress two nights weekly, and have a mattress on the other nights"! We are not prepared to express a sweeping condemnation of the system of plank beds; no doubt to a large number of our criminals they are no great hardship; but we venture to think that they should not be enforced universally, and if employed should form part of the sentence, and be left to the discretion of the judge or magistrate, subject only to a subsequent reduction of the penalty on medical grounds and advice. But whilst admitting that they may be used in the restricted manner we have suggested, we would emphatically denounce the physiological error of constantly altering a prisoner's sleeping arrangements, especially when engaged in hard physical labour. We consider it not only an act of unnecessary tyranny, but likely to induce serious disease, and its employment in this form will increase the already excessive mortality from pulmonary disease among prisoners that was commented upon at the late inquest.

The new system of prison diets came into force on the 15th May last, and in THE LANCET, May 25th, we gave a resumé of the chief points of interest connected with them, together with full tables of the diets of different classes. Commenting upon these, we objected to the diet of Class 2, for men with hard labour, as being too severe, and certainly insufficient for their physiological requirements. With regard to the novel step of substituting fat bacon and beans for fresh meat on one day in the week, we believed this to be a step in the right direction, but regarded it as simply an experiment. Now it is the essence of all experimental inquiry that the results should be carefully watched and recorded. Though the principle may be theoretically correct, yet, dealing with an already extremely restricted dietary, it is a question whether the withdrawal of four ounces of fresh meat and the substitution of nine ounces of beans and one ounce of bacon is practically justifiable. We have looked in vain through the report for detailed statistics on this point, but have had to content ourselves with the statement that the Commissioners have " every reason to believe that it furnishes sufficient, and not more than sufficient, amount of food to all persons who are subject to it." Like a Nasmyth hammer, it is powerful enough to depress the sturdy criminal and make its infliction a terror to him without acting injuriously on the weak-a physiological paradox at present beyond our powers of solution.

While on the question of diets, we would draw earnest attention to that provided for infants born in local prisons or received therein with their mothers in cases in which the nursing powers of the mother are defective. We give the scale in full :--Diet for infants, under three months, at the discretion of the medical officer; from three to six months, half a pint of milk daily; from six to nine months, six ounces of bread and one pint of milk daily, and half a pint of beef-tea three times a week.

The regulations for infants under three months and over six months are dictated by common sense and humanity; but why punish infants between three and six months by such a limited allowance of milk? Medical men are fully aware that the amount of milk required by an infant at this age varies considerably with the individual, and we have high authority for stating that the average allowance ought not to be less than one pint; in many cases more is required. Surely this is a point that ought to be left to the discretion of the medical officer. We have no right to punish the child as a criminal.

Lastly, with regard to the punishment of ill-conducted prisoners. By Section 43 of the Act the governor of the prison is not allowed to confine a prisoner in a punishmentcell for more than twenty-four hours. We are informed, however, that soon after the first meeting of the Visiting Committee at the Clerkenwell House of Correction "they found that the governor was confining prisoners for longer periods in their own cells on bread and water. They remonstrated with the governor, who replied he was in the right, as the cells in which the prisoners were confined were not punishment cells." Now, practically, since the introduction of plank-beds there is no difference between an ordinary and a punishment cell. Consequently the justices, thinking the governor was exceeding his duty, appealed to the Home Secretary, who, most unaccountably, as we think, decided in favour of the view of the Act taken by the governor. We are not surprised that the jury, having the full circumstances of Nolan's death before them, expressed an opinion that "all kinds of repeated punishments should only be administered under the authority of the Visiting Justices."

In conclusion, we would express our decided conviction that the system of prison discipline is still very defective, and that to many criminals it is most unjust. We have no foolish sentiment towards the criminal classes, but we feel that if further inquiries like that just concluded by Dr. Hardwicke take place, an expression of public feeling will be manifested which will cause an undoing of much that is salutary in the prison system, and we shall go to the extreme of undue leniency. By all means, let us punish criminals to the full extent of their physical endurance, but not beyond; and, in order to do this safely, it will be necessary to keep a constant watch over each individual prisoner and regulate his task and diet accordingly, and not group them into classes as at present. And we would further urge the necessity, in all cases where punishment is inflicted in prison for idleness or obstinacy, that careful thermometric records of the prisoners' temperature should be taken, lest the supposed idleness be found too late to be due to pneumonia or tuberculosis.

\section{Cortespondence.}

$$
\text { "Audi alteram partem." }
$$

\section{HAMPSTEAD SMALL-POX HOSPITAL.} To the Editor of THE LANCET.

SIR,--I have read your leading article on this subject (Dec. 7th) with very great surprise and disappointment. The verdict of the jury, if allowed to stand, will be dangerous, if not fatal, to the plan for treating epidemic diseases which was adopted under "Gathorne Hardy's Act." That verdict rests upon considerations which no one can discover in the imperfect reports of the long trial given in the daily newspapers. You have given no report at all, I believe. Your leading article does not in any way explain why you agree with the jury in considering the Hampstead 
Hospital a nuisance to the plaintiffs per se, and also a nuisance on account of its management, except it be that you think the site a bad one, and that you think the approach to it such as to render probable some communication between the ambulances or sick-conveyances and the persons in the road. I hope you will not consider that I am trespassing on your space if $I$ ask you to speak a little more plainly on this subject, and if $\mathrm{I}$ beg to be allowed to put before your readers a few facts on the other side. I only write in discharge of what I think my duty, having been a member of the Committee of the Asylums Board, which first selected and recommended this site. Had my esteemed friend Dr. Sibson been alive, I would willingly have left the matter in his far abler hands. His advice on this subject had naturally far more weight than mine, as I am only a surgeon, and have no special knowledge of epidemic diseases, while he was one of the most accomplished and painstaking physicians of his day. We both belonged to the Board for the first few months of its existence, and were both still members of it when the selection of this site was originally opposed by the neighbours. At that time all the medical members of the Board, and the medical advisers of the Local Government Board, were fully convinced that the site was admirably adapted for the purpose of receiving and treating cases of infectious fever, and that no harm could arise to the neighbours if the place were properly managed. Nor did I understand that the selection of the site was in question at the trial. In consequence of my former connexion with the Board, I was subponaed to attend the trial, but was told by the counsel and solicitor for the Board that the selection of the site was not contested, and that therefore I need not give evidence. I conclude therefore that the verdict, which you say expresses the common-sense view of the case, must rest upon some other considerations than those which you bring forward in relation to the site itself. Yet I would not willingly leave these without reply. You refer to an article by a special correspondent of your own in December, 1874. I read that article at the time, and have reperused it; yet I cannot see that it in any way supports the present verdict. Your correspondent's report appears to me to be entirely in favour of the site. ${ }^{1}$ It shows its ample extent-more than eight acres. It shows that you are in error in believing that there is only one access to the groundthat from the main road-for there is another, and a much better one, from Fleet-road, which is closed only by the obstinacy of the owner of the property bordering on the road, who is, I am told, one of the plaintiffs, though I cannot take it on myself to affirm this latter fact of my own knowledge. You speak of the present buildings, as if those in which patients are treated and the exercising grounds in which they walk were close to the neighbouring houses. If you would go to the place itself you would see that the shed which is nearest to the houses owned by one of the plaintiffs is only occupied by convalescents, who are not permitted to walk in the ground separating it from the back gardens of the houses. It is true that the attendants are allowed to walk in this ground, and that the inhabitants of the houses, if they choose to climb their own garden walls, can enter into communication with these attendants if the also climb the wall : and this no doubt might be dangerous if the inhabitants choose to remain unvaccinated. But there is no proof, as far as I know, that anything of the sort ever took place; if it did, it would certainly be as much or more the act of the inhabitants than of the Asylums Board, and the possibility could be obviated in a day by putting chevauxde-frise or some broken bottles on the wall. As to what has been said about alternative sites, I can only say we saw none which seemed to us so eligible in every way as the Bartrams, though we searched patiently the whole northern district of the metropolis, with the aid of the most experienced land agents. After this site had been purchased, it is true, some others were suggested by the inhabitants of Hampstead, but the Board thought them ineligible, and they would, I believe, have been exposed to exactly the same legal objections. For it must be recollected that the inhabit ants of Hampstead are not singular in their objection to having a small-pox or fever hospital in their vicinity; exactly the same objection was felt some years ago in Islington

1 After alleging some minor objections to the site, immaterial in any case, and I believe deriving no support from the experience which has now been obtained of it, the report concludes very sensibly, "But we cannot see that the Board would be justified in abandoning it on these
grounds only. To sum up, we believe that most of the supposed grounds only. To sum up, we believe that most of the supposed readily obviated by proper precautions. when the Fever Hospital was removed therc. The value of property around was said to have fallen to one-half. But the proprictors were too poor or not speculative enough to try the chance of law. The alarm subsided when time had shown its groundlessness-as this would have done if the present action had terminated otherwise, - and no one now thinks anything about the matter. The only argument, in fict, which I have seen to show that the hospital is a nuisance per se is that which you have justly denounced as merely trumpery and "ad captandum"-viz., that cases of small-pox have been more numerous near it than the ratio calculated for the parish generally. Yet this is the argument triumphantly brought out in The Times by Mr. Pearson Hill and others, and is the one which doubtless weighed most with the jury. So dangerous is it to leave medical questions to be decided by persons necessarily quite ignorant of the matter. If it is sufficient to prove a hospital a nuisance to prove that people do not like to live near it, then no hospital for infectious diseases-nay, hardly any hospital at all-could be established in a city without being indicted. But if that were the law (to say nothing of its absurdity) the Legislature would never have directed the establishment of such hospitals. Another argument which is much used is, Why was this hospital placed at Hampstead -why not further off, as at Highgate, or still further in the country? In the first place, what would have been the advantage? If Sir Rowland Hill can claim damages from this hospital, the premises of which only adjoin his field, and the approach to which would have been entirely away from his house but for the obstinacy of a person who, as I believe, has also claimed damages, why should not someone at Highgate do the same? To any un. prejudiced observer, I should have thonght Sir Rowland Hill would appear to be in no more danger from the hospital than the Duke of Wellington at Apsley House. As to any annoyance, I doubt if the hospital premises are even visible from his back windows; if they are, a few trees would soon hide them. The house itself is quite away from the hospital premises. And as to the approach of patients annoying him-if it really does so, he may thank the proprietor of the Fleet-road. So with the other plaintiti, Mr. Lund. His building property, we are told, has been depreciated. Possibly for a time it has. But would not a similar effect have followed wherever it was placed, if it were in any suburb at all? And to go into the open country is, in the present circumstances of London, impossible. The Board is represented as having (in the cant of the day) "fixed a hard and fast line" at three miles from the centre of the metropolis. I do not suppose they ever did so, but in litigation it is a very common trick to lay hold of some casual expression of this sort used by your adversary and represent it as being proposed by him as a fundamental proposition. All that was said at the time was that it was desirable to have as short a distance as possible to transport these fever patients, ${ }^{2}$ and that three miles should be looked upon as about the furthest distance which, as a general rule, patients ought to have to travel. It must be remembered that in times of epidemics the number of patients, very severely ill, and of their friends, is very considerable. Much loss of life and great hardship and distress would follow, if the hospital were situated far from the centre of the city. We wished to have placed it in a much more central situation, but were prevented by the fact that the Board had no compulsory power. of purchase. In times when there is no epidemic, and when, therefore, some of the hospital establishments are broken up, it is necessary to send the sporadic cases which occur a longer distance; but that which is necessary under exceptional circumstances is not thereby shown to be best as a rule. As to the ambulances, though you praise the common sense of this verdict, I cannot but think that your own view is much more in accordance with common senseviz., that it is hard to see how the plaintiffs can be held entitled to damages on that account, unless they can show that they themselves suffered some harm. If they are entitled because the general public is thought to be en. dangered, why should not you and $I$, who are equally members of the public? Now, I will not deny that the present system of conveyance of patients is susceptible of

2 Here, again, I am happy to avail myself of your special corre. spondent's report. "The large number of cases of small-pox admitter from St. Pancras in the epidemic, and the constant prevalence of fever in that parish and in St. Giles's and Holborn, show the necessity for some near means of isolation; and experience has conclusively shown that the number of cases that can with safety be removed diminishes greatly with increased distance from the hospital." 
amelioration. I do not see that any real harm has been proved to have occurred, except in the instance of the wife of one of the plaintiffs, Mr. Fripp, who looked into one of these sick carriages and is said to have so caught the disease ; but if it is true that these carriages have been allowed to stop at public-houses for drink or cliat, it is clear that danger might be caused; and even in Mrs. Fripp's case, though it may be true that she owed her calamity to her own imprudence, it is clear that the occurrence ought to have been rendered impossible. It should be known, however, that these carriages are not the property nor under the control of the Board. They belong to the individual vestries. I think a far more effectual precaution than the "disinfection" spoken of by the jury would be to place the carriages, as well as the reception and treatment of the patients, under the control of the Asylums Board, who would be responsible for their proper regulation. And let it not be forgotten that even if we were obliged to conclude that there is distinct evidence of unavoidable danger in moving small-pox and fever patients to hospital (the contrary of which, I contend, is the conclusion to which all experience points), yet we must compare this with the danger of leaving them at home. I have heard it stated that Dr. S. Gibbon told the jury that he believed the two recent epidemics of small-pox were so severe in consequence of the patients being carried through the streets. May I inquire if this is true? and, if so, on what grounds Dr. Gibbon made the statement? One would have thought $\dot{c}$ priori that any slight risk involved in the carriage of the patient would have been as nothing compared to the rast benefit derived from his subsequent isolation.

As to any disregard of the rights of the inhabitants of Hampstead, I must say that I am totally unable to discover any thing to support such a charge. The hospital was placed there because there only did we think we could find a suitable site. The Managers then believed, and still believe, that no danger whatever would accrue from it.

I find a general impression prevails that this hospital in some way obstructs the way to Hampstead Heath. Those who have been to the place know how absurd this is ; still I think it as well to say that no one going to the Heath from any part, or by any road, need see or know of the existence of the hospital, nor is he in any greater danger of catching small-pox from passing along the road, out of which the lane opens in which the hospital is placed, than he would be of atching fever by driving along the Liverpool-road, or of catching small-pox by a visit to Highgate. This argument also has been used to create an impression on the public, but cannot have been seriously believed in by anyone who is acquainted with the circumstances.

I have, I fear, been prolix, but the subject is so complicated, and, I find, so generally misunderstood, that I have been unable to avoid writing at some length. Let me conclude with an earnest appeal to the medical men who thought it their duty to give evidence on behalf of the plaintiffs, and especially to the respected President of the College of Physicians, to explain their evidence, or, at any rate, to see that it is published in extenso. The latter especially, from his public position, is bound not to oppose the action of a public body taken, as everyone admits, with the single object of carrying out the beneficent intentions of the Legislature, except for the gravest reasons. If public danger had been caused by the action of the Asylums Board-if real proof had been within his knowledge of the spread of smallpox or fever in consequence of their mismanagement-if he had reason to know that the interior arrangements or treatment of the sick had been bad, then I can imagine that the President of the College would feel it his duty to interfere. But if he was brought there, as the slight sketch of his evidence in The Times seems to show, merely to add anthority to the names of the medical witnesses for the plaintiffs, and to tell the jury what everyone knew before-viz., that no one likes to live near a small-pox hospital-it may be questioned whether he should have lent himself to such a manouvre. In any case the managers have a right to ask so great an authority, as he has mixed himself up in the matter, for counsel as well as criticism.

December 10th, 1878 I am, Sir, yours \&c., Holmes's letter, but as a statement of the views of the Board it is worthy of consideration. The points of difference between Mr. Holmes and ourselves appear to be minor matters of judgment, and to rediscuss them in detail would occupy too much of our space. The general opinion which we expressed we adhere to, for, whoever may be responsible for the closure of the Fleet-road access, it is only one and not all the plaintiffs, and the mere fact that it was so far a private road that it could be closed, and that the Board did not ascertain this fact, shows that they did not act with proper caution. Nor, on the other points of difference, do we think that the view adopted by Mr. Holmes would be generally accepted by uninterested persons. The discrimination of convalescent wards can hardly be made from their external appearance, nor do we suppose that there can be any rule which will always be enforced that the ward nearest the boundary wall will be used for none but convalescents. We have yet to learn that small-pox is not lighly contagious from convalescents.-ED. $\mathrm{K}$.

\section{THE ACTION OF HYOSCYAMINE AND ITS RELIABILITY.}

\section{To the Editor of THE LANCET.}

SIR,-The question of the reliability of a drug is a most important one, and the varying effects of different samples may give to different observers very erroneous ideas of its action, and consequent dose.

I have hitherto found Merck's extractive amorphous alkaloid, obtained through Messrs. Harvey and Reynolds, of Leeds, a very reliable and uniform preparation, and entirely corroborate Dr. Lawson's observations, which appeared in THE LANCET recently. I have had many samples, each obtained in the same way, and have noticed no variation in the effects produced on the same patients, some of whom have been taking the drug at intervals for many months. Very lately, however, I have received two samples which certainly have proved almost, if not quite, inert. The hyoscyamine I had hitherto received was of a dark brownish colour, with a slight dirty-greenish tinge, and of a peculiar disagreeable smell, almost mousey; but a sample which I received a few weeks ago was of a much lighter colour, almost a golden brown, with a smell more like that of gas liquor than anything else. I noticed the difference in colour, and the attendants drew my attention to the fact that the medicine did not produce the same effect as that which the patients had previously taken. I increased the dose, but could not find that it produced any of the physiological effects of the previous samples. I wrote to Messrs. Harvey and Reynolds; they admitted that there had been a difference in the colour of the preparation, and regretted that it should vary, and they kindly sent me a fresh sample. I noticed that this was of the same light colour, and, having doubts as to its efficacy, I determined, if possible, to test it carefully, and compare its action with that of the former samples. I obtained from a friend, Dr. Swanson, of York, a small portion of a sample of the alkaloid procured from Messrs. Harvey and Reynolds some months back, and which was of the same colour that my previous samples had been. I then made up a solution of each in the same way, and to give a clear idea of what the difference in colour was, I found that in a solution-one grain to twenty-four minims-the colour of the new sample was as nearly as possible that of tincture of myrrh, and the colour of the older that of tincture of digitalis. I selected two patients who had previously taken hyoscyamine, and were particularly susceptible to its action-a patient, A. B., suffering from epileptic mania, and a patient, C. D., a case of pure mania. On successive days I gave each a dose of hyoscyamine, and at the same time. On the first day, they each had a dose of one-eighth of a grain of the last sample of the alkaloid, and I saw and watched them closely during the ensuing four hours. The pupils of the patient A. B. measured $1+1$ lines at the time of administration of the drug, and during the four hours no variation beyond an immeasurable one took place; there was no observable change in her in any way, her condition remained loud and boisterous. The pupils of the patient C. D. measured $1 \frac{1}{4}$ lines at the time of administration, and four hours afterwards the greatest measurement had been $1 \frac{1}{2}$ lines. There 